\title{
Analysis of Perception and Public Preference on Reputation of Higher-Education Ranking Agencies
}

\author{
Muji Gunarto \\ Management Program Study, FEB \\ Univeritas Bina Darma \\ Palembang, Indonesia. \\ mgunarto@binadarma.ac.id
}

\author{
Dimas Yudistira Nugraha, Vanessa Gaffar \\ Management Program Study \\ Universitas Pendidikan Indonesia \\ Bandung, Indonesia. \\ dimasyn@student.upi.edu
}

\begin{abstract}
The Minister of Research, Technology and Higher Education of the Republic of Indonesia has classified and ranked national universities. Previously, some rating agencies have classified and ranked college and universities both nationally and globally. The objectives of this study are to analyze public perception on the reputation of the rating agencies and to investigate community preferences in selecting a college or a university. Survey method conducted on some of students, lecturers, and general public. The sampling technique is accidental sampling. The number of respondents is 123 respondents. The analysis technique is descriptive analysis and conjoint analysis. The results show that most of the respondents do not recognize on independent higher-education ranking agencies' result, most of the respondents recognize BAN-PT only. However, the results of higher-education ranking are taken seriously by the leaders and the managers of college and university. They take it as a basic policy to achieve the best higher-education. In addition, the public preference towards college or university shows the high score with various aspects of consideration because they should be able to give more value to the public. Almost all aspects of preferences have high rank, except for the aspect of prestige. The highest preference in selecting a college or a university is reputable aspect and program study that conformity with student's interests.
\end{abstract}

Keywords- consumer perception; preference; HigherEducation Ranking Agency.

\section{INTRODUCTION}

In Indonesia, the competitions among colleges and universities are very competitive. This phenomenon occurs in the presence of Private Higher-Education, which are growing rapidly [1]. The number of Higher-Education in Indonesia are currently at 3,193 universities. The total of Public HigherEducation are 121, while Private Higher-Education are totaled 3,072 . The overall number of students are 6,749,825 students (Public Higher-Education $=2,224,718$ and Private HigherEducation $=4,525,107$ ) [2]. The phenomenon today is, it is very easy for Public Higher-Education to get the student, but for Private Higher-Education, they must strive to get the student.

In selecting a college or a university, prospective students will consider the characteristics of the product which includes the value of accreditation, quality, and infrastructure. Then, the second factor is the price (tuition), which covering the first entrance fee and the tuition fee per semester. Pricing will affect the buying behavior for prospective students. Prospective students will select a college or a university at an affordable price. The third factor is the location; students will select a college or a university with a strategic location and convenient location. The next factor is the promotion; it is important for college or universities to introduce to their prospective students [3].

Student preference in selecting a Public Higher-Education is not for price consideration. It is because a tuition in the Public Higher-Education, is relatively close to the tuition in the Private Higher-Education. Prospective students select a college or a university by considering the trust, the image of college/university, the quality of service, and the satisfaction [4].

There are 5 (five) assumptions from society in considering the internationalization of Higher-Education. The five assumptions include: 1) the Higher-Education hopes that foreign students will deliver their culture, and the HigherEducation more internationalizing the curriculum, but the fact is that most foreign students feel marginalized both socially and academically; 2) the international reputation which is perceived as a quality for the college/university, does not always implement to the improvement of the quality or high standard; 3) cooperation with many international institutions, but in fact, many institutions are not able to manage or get the benefit from the agreements that have been made; 4) international accreditation from various countries, especially from the US, is quite popular among the university; and 5) the passion for the internationalizing the college/university is to make the brand globally is an incorrect assumption. However, the five assumptions are not applicable to all universities in all countries; the assumptions only describe general assumption from public perception [4].

The Ministry of Research, Technology and Higher Education of the Republic of Indonesia has classified and ranked college or university nationally. Then, the result is announced every semester [2]. The assessment criteria include quality of human resources, quality of management, quality of student activities, and the quality of research and publication. Previously, BAN-PT (National Accreditation Board - Higher Education) was the only institution that performs the classification of the universities in Indonesia with rank A, B and $\mathrm{C}$ to a college or a university. Today, the college or the university is also able to know the world rankings which done 
by the international higher-education ranking agencies. The international university ranking agencies include the Time Higher Education QS World University Ranking (THE-QS) and the Academic Ranking of World Universities (ARWU).

All higher-education ranking agencies have differences in the assessment criteria and some agencies focusing on the quality of teaching. [5]. The emergence of global highereducation ranking which issued by ARWU and THE-QS have attracted the attention of academics and policy makers, which connected to "knowledge-based economy dynamic and competitive in the world" [6]. The emergence of global higher-education rank is not only challenging, but also can be a stimulus for changing college/university policy in Europe [6]. In addition, Pusat Data dan Analisa Tempo (PDAT) annually conducts a survey for investigating the best colleges/university in Indonesia in terms of the work environment. Pusat Data dan Analisa Tempo (PDAT) selects this method because the perception of the alumni based on their knowledge and their experience during they were in the college or the university and how they work with others alumni from other colleges/universities [7].

The results from higher-education rank have affected many critical issues that related to the performance of the college and the university. They gain some contributions, such as planning and strategic positioning, staffing and organization, quality assurance, resource allocation, marketing and fundraising, admission and financial aid, student and academic mobility, and more others. All these things are important in the context of the new paradigm of the higher-education and the global competition in increasing the talent, resources and prestige, as well as related to the status of world-class colleges/universities [8].

Academic ranking agencies which focus on the courses and the departments of colleges/universities have been widely recognized by the general public. There are many agencies that perform the national higher-education ranking. Besides, at least there are only two international agencies that perform ranking colleges/universities. Nevertheless, the result is much criticized because its method is considered inaccurate or questionable, yet many people still attend the results [9]. Assessment to measure the quality of research and the teaching programs in universities have been conducted. Nonetheless, many contemporary assessments of ranking are calculated by the commercial media which is driven by the profit motive and the targets are for the prospective students and parents [10].

The process of ranking colleges/universities into something interesting because it can be a challenge and a selling point for the college or the university management, but on the other hand, it can be a dilemma because the measuring instruments applied are varied from one agency to other agencies so that the results are different. For example, BANPT assessing the quality of education through the aspects of curriculum, facilities, research, faculty, students and the prospects of its graduates. While other agencies, apply different methodological approaches. It is becoming something of interest for researchers to assess how people's perceptions and preferences on reputation of university ranking agencies. However, the methodology applied by the agency into a debate regarding practicality and accuracy of the ratings.

In general, this study aimed to determine perception and preference of society on the reputation of the higher-education ranking agency. As well as to build up a map of potential universities in Indonesia. In detail, these goals can be explained as follows:

a) To identify the characteristics and the public perception of the reputation of the college rankings.

b) To analyze people's preferences in choosing a college or a university.

\section{LITERATURE REVIEW}

\section{A. The College and the University Rankings Agencies}

World university ranking agency is an institution which ranks universities worldwide with diverse combination of factors assessment. The ranking is done by various institutions, which coming from an organization, magazines, newspapers, websites, government, or university. The institution is not just to rank a university, but also provide ratings based on a program, department and faculty. However, there is still no institution that ranks the quality of a student's academic.

Institutions that conduct university rankings, not only carried out by an institution, but there are some websites that are also commonly used as reference ranking universities. Here are the names of institutions and websites referenced ranking universities in the world and Indonesia; they are:

1) QS World Ranking. This agency applies several methodologies in the assessment of the university, such as the number of students (Size), the number of program studies (Focus), Total Research \& Publication indexes (Research), and the University Age (Age).

2) 4ICU. 4ICU (4 International Colleges and Universities) is a website that does the rankings of the best universities. The method applys in compiling the list of college is to look at the index algorithm based on multiple independent search enginessuch as Google Page Rank, Yahoo Inbound Links, and Alexa Traffic Rank.

3) Webometrics Ranking of World Universities (Webometric). Webometric also very well known as a trusted site as a rating of universities in the world. This site uses four parameters to measure and rank colleges. The parameters are Presence (20\%), Impact (50\%), Openness (15\%), and Excellence (15\%). Excellence parameter is the number of scientific articles published on the college website and indexed in Scimago Institution Ranking and Google Scholar.

4) TeSCA. PT Telekomunikasi Indonesia is State-Owned Enterprises (SOES), which is also concerned with the development of education in Indonesia. Telkom also has a program awards for the best university in Indonesia, namely, TeSCA (Telkom Smart Campus Award). However, the awards 
only looked at the aspects of ICT (Information Computer Technology) course.

The various agencies make evaluations by various criteria and methods, so that the results from one institution to the other institutions are different. Websites usually evaluating from the popularity of websites belonging to universities based on several factors, such as the number of website visitors, backlinks to the website, the published scientific papers and more.

\section{B. Consumer Perception}

Perception is "the process when a person chooses, organize and interpret information that comes into its own to create a sense of the overall picture." [11]. This information can be defined as everything that comes in and created a sensation to a person, it can be a product, packaging, branding and advertising. Perception as the way a person sees the world around him [12]. Two individuals may receive the same stimulus in the same conditions, but the way in selecting, organizing, and interpreting the stimulus may be different depending on the needs, values and expectations of the consumer. Perception is defined as the way people select, organize, and interpret stimuli into the meaningful picture. Meanwhile, [13] defines perception is a process where a sensation is selected, organized, and interpreted. External stimuli or sensory input can be received in the various channels. Input brought by the five human senses is the raw data that will start the process of perception.

Perception is formed through four stages, namely stages of exposure, attention, comprehension, and retention phase [14]. This theory is a theory of customer perception as a subjective assessment of the quality attributes reputation of universities [11]. Perception of quality is relating to the benefits of each attribute [15].

\section{Consumer Preference}

Estimating the future behavior of a consumer, particularly their purchasing behavior, is a very important aspect in forecasting and planning marketing. Forecasting consumer buying behavior is an issue of measurement desire from the consumer to buy and right before they make a purchase [16]. The issue of price is a sensitive issue at the university. Universities that offer cheap prices are closely related to lower quality, although some people will refer different things related to the price [17].

Consumer preferences indicate consumer preference from a wide selection of products and / or services exist. Thus the preference theory can be implied to analyze the level of satisfaction for the consumer, for example, when someone wants to consume or use a product or service with limited resources, then he should choose the alternative that uses the value or the utility to achieve optimal [18].

Consumer preferences can be determined by measuring the level of usability and value of the relative importance of each attribute contained in a product or service. Attributes are displayed on a product or service. It may give rise to the appeal of the first that could affect consumers. Assessment of the products and services describe the attitude of consumers toward the product or service, as well as to reflect consumer behavior in using or consuming a product or service [19]. Preferences can also be used to measure the scoring system [20].

Consumer perceptions about a product will form a preference. Consumer preferences can mean joy, options or something more preferred by consumers. Consumer preferences related to consumer expectations of a product he likes. Consumers' expectations are believed to have played a large role in determining the quality of products (goods and services) and customer satisfaction. Consumer preferences defined as an option liked or disliked by someone of the products (goods and services) are consumed.

\section{RESEARCH METHODS}

Design of this research is descriptive and verification. Descriptive study aimed to obtain clearly about a situation or circumstances, whereas the verification study aims to determine the clarity of the relationship of a variable with data collection in the field. The method used is a survey method which takes a sample of the population using questionnaires and observation as the primary means of data collection.

The study population was all Indonesian people. The target population is people in Bandung. The sampling technique used was accidental sampling, the sampling is based on respondents who easily found. In this research, the total sample of 123 respondents from the three characteristics, namely students, lecturers / teachers and the general public.

Processing and data analysis by descriptive and inferential. Descriptive analysis performed by presenting data summarization through descriptive statistics. While inferential analysis is done by using one of the techniques that conjoint analysis Multivariate analysis [21]. Conjoint analysis is a technique to measure consumer preferences for products or services. Conjoint analysis is based on the subjectivity of consumers against some combination of features offered [22]. Interest conjoint analysis is to obtain a score of usefulness (utility) that can represent the interests of every aspect of college, so on that score it can be deduced about the attributes of what most consumers consider in choosing a college.

Conjoint analysis results in the form of quantitative information that can model the consumer preference for some combination of product features. The calculation process in the data analysis done by Microsoft Excel data processing and statistical data processing software package SPSS for Windows.

\section{RESULTS AND DISCUSSIONS}

\section{A. Characteristics of Respondents}

Characteristics of respondents viewed by age, gender, main occupation, religion / belief, the best universities, and renowned rankings institutions. Based on the age, the distribution of respondents looks like in Fig. 1. By sex, $63 \%$ of respondents were female and the rests (37\%) were male. Distribution of respondents by sex is presented in Fig. 2 . 


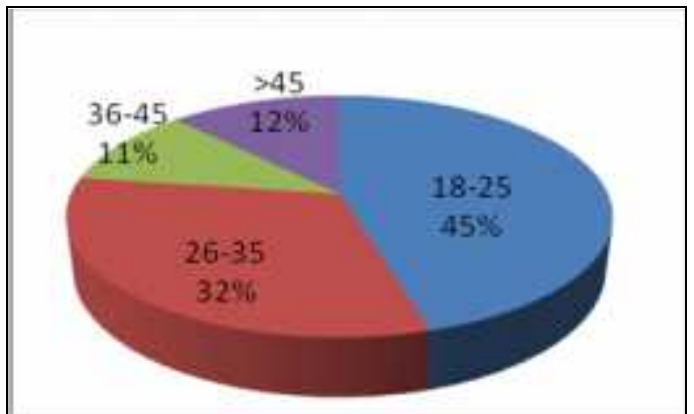

Fig. 1. The distribution of respondents based on Age

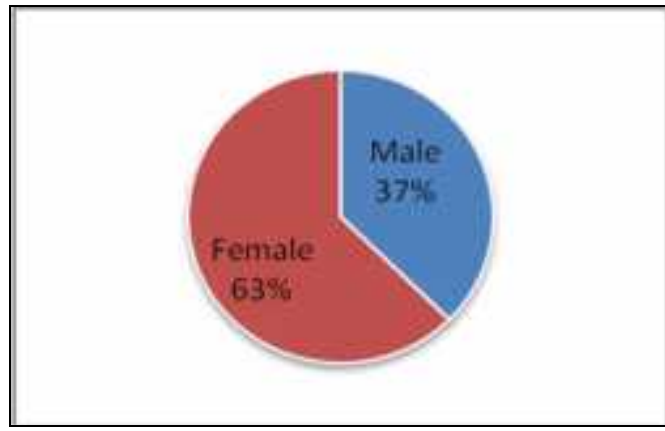

Fig. 2. The distribution of respondents based on Sex.

Based on the main job, most of the respondents were students (62\%), $27 \%$ of teachers / lecturers and the remaining $11 \%$ of the general public (Fig.3). The distribution of respondents by religion is presented in Fig. 4.

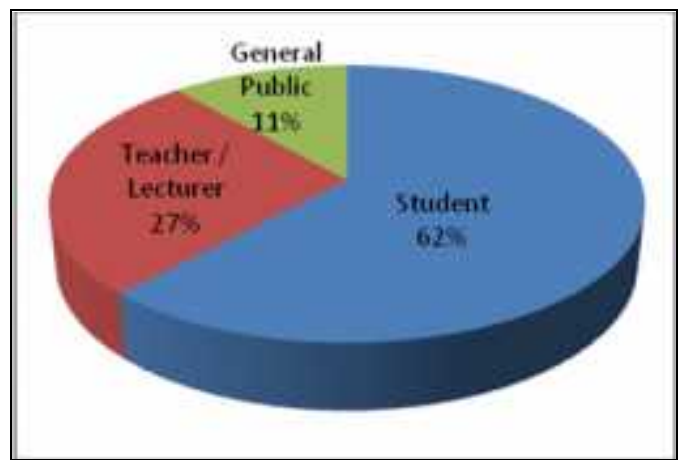

Fig. 3. The distribution of respondents based on Job.

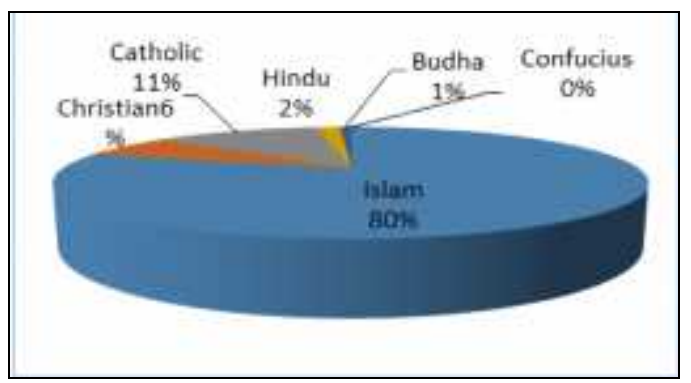

Fig. 4. The distribution of respondents based on Religion.

Based on the Best Universities in Indonesia according to respondents, the majority of respondents mentioned ITB $(27 \%)$ as the best universities in Indonesia, 20\% said UGM, $18 \%$ cite the UI, $9 \%$ UNPAD and the remaining $26 \%$ cite a wide range of universities (Fig. 5). The distribution of respondents by the rating agency known universities are presented in Fig. 4. Most respondents only know BAN-PT as an institution that performs classification and grading, there were $19 \%$ cite DIKTI, and the rest said foreign institutions.

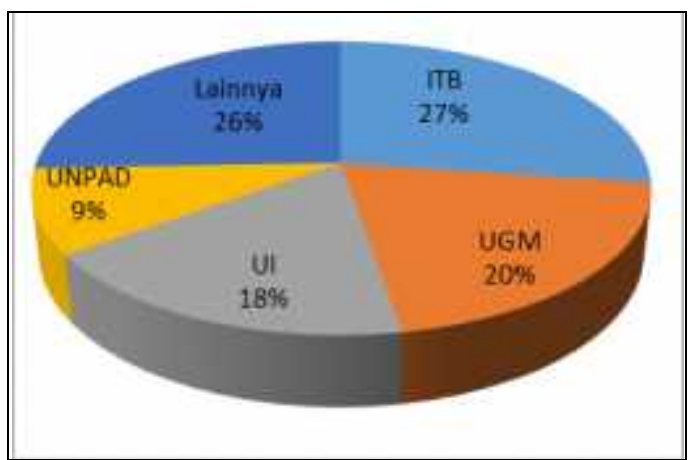

Fig. 5. The distribution of respondents based on the best University.

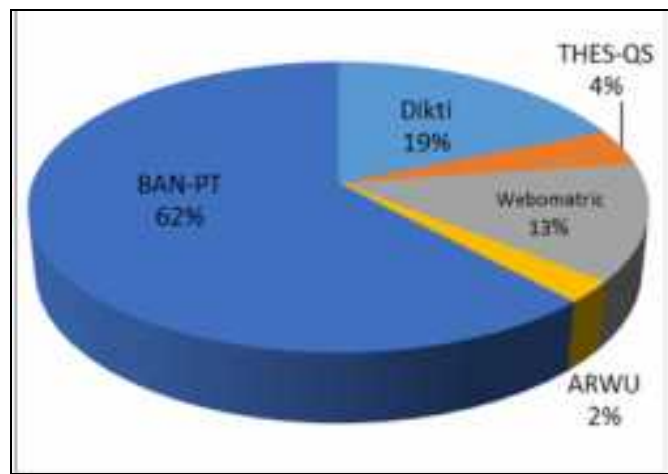

Fig. 6. the distribution of respondents based on the well-known rating university agency.

Fig. 6. shows that respondents rank or pay less attention to the college and the university ranking agencies. Most of the respondents only know accreditation from BAN-PT.

\section{B. Public perception towards the College and the University Rankings Agencies}

The public perception of the college and the university ranking agencies both nationally and internationally are presented in Table I.

In general, the public perception of various indicators or attributes of the college and the university ranking agencies is in the middle category $(66.6 \%)$. This shows that the public perception is not strong regarding the results. Each attribute rating shows that the public perception of the independence of rating agencies is relatively highest among other attributes. While the attribute that has the lowest perception among others is that the agency can become the reference in choosing a college. This shows that when choosing a college is not considered from rank or classification made by the rating agencies both nationally and internationally. This condition also illustrates that the public is less concerned with the rating or classification that has been done by various rating agencies universities both national agencies and international institutions. 
TABLE I. PUBLIC PERCEPTION ON THE COLLEGE AND THE UNIVERSITY RANKING AGENCIES

\begin{tabular}{lllllllll}
\hline \multicolumn{1}{c}{ Aspects of Assessment } & SD & D & UD & A & SA & Score & $\begin{array}{c}\text { Max } \\
\text { Score }\end{array}$ & Percentage \\
\hline Professional Institutions & 9 & 18 & 27 & 55 & 14 & 416 & 615 & $67,6 \%$ \\
Independent Institutions & 6 & 14 & 23 & 57 & 23 & 446 & 615 & $72,5 \%$ \\
Objective in the assessment & 1 & 25 & 38 & 47 & 12 & 413 & 615 & $67,1 \%$ \\
Using a good instruments & 11 & 9 & 34 & 58 & 11 & 418 & 615 & $67,9 \%$ \\
Accountable & 10 & 19 & 34 & 42 & 18 & 408 & 615 & $66,3 \%$ \\
Good reputation & 8 & 22 & 28 & 46 & 19 & 415 & 615 & $67,5 \%$ \\
Open process & 14 & 19 & 35 & 34 & 21 & 398 & 615 & $64,7 \%$ \\
Can be a reference in choosing a college & 13 & 31 & 38 & 31 & 10 & 363 & 615 & $59,0 \%$ \\
Using complex methodology & 9 & 18 & 30 & 54 & 12 & 411 & 615 & $66,8 \%$ \\
Total & $\mathbf{8 1}$ & $\mathbf{1 7 5}$ & $\mathbf{2 8 7}$ & $\mathbf{4 2 4}$ & $\mathbf{1 4 0}$ & $\mathbf{3 6 8 8}$ & $\mathbf{5 5 3 5}$ & $\mathbf{6 6 , 6 \%}$ \\
\hline
\end{tabular}

${ }^{*} \mathrm{SD}=$ Strongly Disapprove, D=Disapprove, UD=Undecided, A=Approve and SA=Strongly Approve.

These results are consistent with research that says that students' perception of the quality of higher education is more on experience on campus, where they can provide added value to the knowledge in them [23]. Perception of quality is qualified lecturers, administrative personnel that can provide services and is open to complaints. This means that the public perceptions of the rating agencies are not so impacted, it is seen from the statement that the consumer in selecting a college is still relatively few who use college rankings as reference.

The impact of the classification and rating only applies to the organizers of the college. Some college/university leaders responded very reactive to the rating conducted by various institutions [6], [24]. It is appropriate from the findings that most people only know the BAN-PT as an accredited institution or college classifier, whereas the rating highereducation agencies are not widely known by the public and the students.

\section{Public Preference on the College/University}

These aspects are considered important by the people associated with various attributes of the electoral college or university; the aspects are price (charges), reputation, location, management, faculty, college atmosphere, research, alumni, prestige, easy pass, infrastructure, and compliance with interests, the results of the assessment of the public preference regarding electoral college attributes shown in the Table II.

TABLE II.

PUBLIC ASSESSMENT ON SELECTING THE COLLEGE/UNIVERSITY

\begin{tabular}{lllllllll}
\hline \multicolumn{1}{c}{ Aspects of Assessment } & SD & D & UD & A & SA & Score & Max Score & Percentage \\
\cline { 1 - 5 } Price & 1 & 7 & 27 & 75 & 13 & 461 & 615 & $74,96 \%$ \\
Reputation & 0 & 1 & 2 & 70 & 50 & 538 & 615 & $87,48 \%$ \\
Location & 1 & 5 & 18 & 77 & 22 & 483 & 615 & $78,54 \%$ \\
Management & 0 & 0 & 4 & 78 & 41 & 529 & 615 & $86,02 \%$ \\
Lecturer & 0 & 0 & 14 & 52 & 57 & 535 & 615 & $86,99 \%$ \\
Atmosphere & 0 & 0 & 8 & 66 & 49 & 533 & 615 & $86,67 \%$ \\
Research & 0 & 1 & 35 & 66 & 21 & 476 & 615 & $77,40 \%$ \\
Alumni & 0 & 1 & 10 & 58 & 54 & 534 & 615 & $86,83 \%$ \\
Prestige & 11 & 28 & 50 & 23 & 11 & 364 & 615 & $59,19 \%$ \\
Easy pass & 1 & 10 & 23 & 60 & 29 & 475 & 615 & $77,24 \%$ \\
Infrastructure & 0 & 1 & 5 & 61 & 56 & 541 & 615 & $87,97 \%$ \\
Interest Consideration & 0 & 0 & 3 & 61 & 59 & 548 & 615 & $89,11 \%$ \\
\hline
\end{tabular}

*) $\mathrm{SD}=$ Strongly Disapprove, $\mathrm{D}=$ Disapprove, $\mathrm{UD}=$ Undecided, $\mathrm{A}=$ Approve and $\mathrm{SA}=$ Strongly Approve

Table II presents the public's assessment of the aspects assessed based on experience and the respondent's assessment with regard to the process of selecting a college/university. Based on the analysis, almost all aspects are at the level of critical and very important. The only aspect of prestige rated fair or poor by most respondents.

Although several key aspects such as the corresponding interest, infrastructure, reputation, management, lecturers and alumni quickly to work are considered to be high by most respondents, but there are also some of the respondents who consider that the preferences for these aspects are still low or even very low. For example, for the prestige aspect, there are 28 respondents who rate is low. If respondents answered "mid" zoned group was hesitant to electoral college from various aspects before, then more respondents are not yet fully convinced of the aspects of the electoral college. This is a challenge to the management of the university to be able to meet the demands of society and the satisfaction of the students. Thus the college management should pay attention to these things. This is in line with the results of research that says that the impact of ranking colleges is the change in policy of the university management in order to achieve the best position compared to its competitors [6], [8].

Public preference towards college choice is relatively high with the achievements of more than $75 \%$, except for the aspect of prestige is low (only 59.19\%). This condition shows that people's expectation of the quality of higher education is also relatively high. This is because the reference consumer can 
mean joy, choice or something that preferably formed from a consumer perception of the product. Consumer preferences related to consumer expectations of a product he likes and is believed to have played a large role in determining product quality and customer satisfaction.
To make a priority, which aspects are considered public by order of importance, can be seen in Table III.

TABLE III. PUBLIC PERCEPTION ON THE COLLEGE AND THE UNIVERSITY RANKING AGENCIES

\begin{tabular}{|c|c|c|c|c|c|c|c|c|c|c|c|c|c|c|}
\hline $\begin{array}{c}\text { Aspects of } \\
\text { Assessment }\end{array}$ & 1 & 2 & 3 & 4 & 5 & 6 & 7 & 8 & 9 & 10 & 11 & 12 & Score & Rank \\
\hline Price & 20,3 & 7,3 & 9,8 & 6,5 & 12,2 & 6,5 & 5,7 & 9,8 & 2,4 & 9,8 & 5,7 & 4,1 & 760,98 & 8 \\
\hline Reputation & 35,8 & 17,1 & 11,4 & 4,9 & 9,8 & 4,9 & 5,7 & 2,4 & 2,4 & 3,3 & 1,6 & 0,8 & 956,91 & 1 \\
\hline Location & 13,8 & 13,0 & 8,1 & 8,1 & 13,0 & 8,1 & 4,9 & 8,1 & 7,3 & 8,9 & 3,3 & 3,3 & 760,16 & 9 \\
\hline Management & 18,7 & 9,8 & 12,2 & 11,4 & 15,4 & 8,1 & 4,1 & 9,8 & 5,7 & 4,9 & 0,0 & 0,0 & 847,15 & 4 \\
\hline Lecturer & 24,4 & 12,2 & 17,9 & 7,3 & 9,8 & 8,9 & 1,6 & 3,3 & 4,1 & 7,3 & 3,3 & 0,0 & 882,93 & 3 \\
\hline Atmosphere & 25,2 & 7,3 & 6,5 & 7,3 & 12,2 & 11,4 & 9,8 & 5,7 & 5,7 & 4,1 & 2,4 & 2,4 & 820,33 & 5 \\
\hline Research & 7,3 & 5,7 & 10,6 & 2,4 & 10,6 & 5,7 & 10,6 & 6,5 & 9,8 & 12,2 & 13,0 & 5,7 & 605,69 & 11 \\
\hline Alumni & 21,1 & 8,9 & 4,9 & 11,4 & 10,6 & 5,7 & 11,4 & 8,9 & 4,1 & 8,9 & 2,4 & 1,6 & 790,24 & 6 \\
\hline Prestige & 5,7 & 1,6 & 4,9 & 4,1 & 7,3 & 4,1 & 3,3 & 2,4 & 7,3 & 13,0 & 6,5 & 39,8 & 411,38 & 12 \\
\hline Easy Pass & 16,3 & 6,5 & 6,5 & 5,7 & 6,5 & 4,9 & 7,3 & 9,8 & 8,1 & 7,3 & 8,9 & 12,2 & 646,34 & 10 \\
\hline Infrastructure & 22,0 & 11,4 & 8,1 & 5,7 & 5,7 & 4,9 & 10,6 & 7,3 & 8,1 & 8,1 & 5,7 & 2,4 & 771,54 & 7 \\
\hline Interest Consideration & 42,3 & 8,1 & 10,6 & 7,3 & 1,6 & 3,3 & 3,3 & 5,7 & 5,7 & 2,4 & 7,3 & 2,4 & 899,19 & 2 \\
\hline
\end{tabular}

The table shows the perception of the level of interest aspects of the electoral college/university according to the respondents. The analysis results show that the first order of interest in the election is a reputable college or university. It shows that in the electoral college or university, reputation or good name is a key element, it can be observed by the number of students who excel, many alumni who are absorbed in the world of work, a lot of achievements both inside and outside the country which is inscribed by the students and the lecturers, and moreover.

The second order of importance is the aspect of respondents rated according to their interests. Respondents wanted that colleges selected for the program of study according to their interests. They choose the courses based on their interests. The ability and the quality lecturers are aspects that according to respondent's importance in the third place. It is also concerned with the reputation of the college.

According to the respondents, the cost of the research is in the order of importance of the eleventh. It means that people's preference to college not because of the amount or quality of research universities, it due to the orientation of students in a college also varies, and most of them expect to be quicker to work, not as a researcher.

The last order of importance according to the respondents is prestige. This suggests that in the electoral college or university, the prestige aspect is the last thing to be considered. It means that the electoral college or university is not for prestige, but rather on the need to learn to be able to enter the world of work. This is consistent with some previous research that says that expectation of the people (students) to college is able to provide value-added, which has the quality of learning and good-quality services [15], [25] - [27].

\section{CONCLUSION}

The results showed that the public perception of college or university ratings agencies are in the moderate category. The results of the classification and rank colleges are not widely known by the public. The majority of respondents only know BAN-PT as an institution that performs the classification of colleges. However, the results of ranking colleges are taken seriously by the leaders and the managers of higher education as a basic policy to achieve the best colleges compared to its competitors.

Public preference on the college or the university is relatively high with across various aspects to be offered. The college or university assessment is an experience. You should be able to provide added value. Almost all aspects of the preferences are highly rated, except for the aspect of prestige. However, only a few people who choose a college or university because of their prestige. The highest preference in choosing a college or university is a college's or university's reputation, and respondents claimed that suitability of the selected program of study with their interest is a very important aspect.

\section{REFERENCES}

[1] M. Gunarto, "Analysis on the Positioning of Private Higher Education Institutions Based on Fields of Science," in 1st UPI International Conference on Sociology Education (UPI ICSE 2015), 2016, pp. 1-4.

[2] Ristekdikti, "Naskah Akademik Klasifikasi dan Pemeringkatan Perguruan Tinggi Indonesia Tahun 2015," 2015.

[3] M. Gunarto and M. A. Syarif, "Penggunaan Analisis Biplot pada Pemetaan Perguruan Tinggi Swasta di Kota Palembang," Forum Manaj. Indones. 6, pp. 1-13, 2014.

[4] J. Knight, "Five Myths about Internationalisation," Int. High. Educ., no. 62, pp. 14-15, 2011.

[5] S. Marginson and M. van der Wende, "To Rank or To Be Ranked: The Impact of Global Rankings in Higher Education," J. Stud. Int. Educ., vol. 11, no. 3-4, pp. 306-329, 2007.

[6] E. Hazelkorn and M. Ryan, "The impact of university rankings on higher education policy in Europe: a challenge to perceived wisdom and a stimulus for change," Glob. Chall. Eur. High. Educ. Converg. Divers. Centres Peripher., 2013.

[7] A. Mulyani, Panduan Memilih Perguruan Tinggi 2014. Pusat Data dan Analisa Tempo (PDAT), 2015. 
[8] J. Sadlak, "Ranking in Higher Education: Its Place and Imact," Eur. World Learn. 2010, pp. 1-11, 2011.

[9] P. G. Altbach, "The Dilemmas of Ranking," Int. High. Educ., no. 42, pp. 2-3, 2006.

[10] R. Brooks, "Measuring University Quality," Rev. High. Educ., vol. 29, no. 1, pp. 1-21, 2005.

[11] P. Kotler and K. L. Keller, Marketing Management. New Jersey: Prentice Hall, 2012.

[12] L. G. Schiffman, L. L. Kanuk, and H. Hansen, Consumer Behaviour: a European Outlook, Second. New Jersey: Pearson Education Limited, 2012.

[13] M. R. Solomon, Consumer Behavior: Buying, Having, and Being, Tenth Edit. London: Pearson Education Limited, 2013.

[14] R. M. Brown and T. W. Mazzarol, "The importance of institutional image to student satisfaction and loyalty within higher education," High. Educ., vol. 58, no. 1, pp. 81-95, 2009.

[15] B. K. Shrestha, "Public perception of the quality of academic education program," J. Educ. Res., vol. 3, no. 1, pp. 52-64, 2013.

[16] J. P. Peter and J. C. Olson, Consumer Behavior \& Marketing Strategy, Ninth Edit. New York: McGraw-Hill/Irwin, 2010.

[17] F. Maringe and P. Gibbs, Marketing Higher Education: Theory and Practice, vol. 1, no. 2. England: McGraw-Hill Education, 2009.

[18] P. Kotler and G. Armstrong, Principles of Marketing, Fifteenth. England: Pearson Education Limited, 2014.
[19] G. Van De Watering, D. Gijbels, F. Dochy, and J. Van Der Rijt, "Students' assessment preferences, perceptions of assessment and their relationships to study results," High. Educ., vol. 56, no. 6, pp. 645-658, 2008.

[20] P. Iannone and a. Simpson, "Students' preferences in undergraduate mathematics assessment," Stud. High. Educ., no. January 2015, pp. 122, 2014.

[21] J. F. Hair, W. C. Black, B. J. Babin, and R. E. Anderson, Multivariate Data Analysis. Pearson Education Limited, 2014.

[22] A. A. Mattjik and I. M. Sumertajaya, Sidik Peubah Ganda dengan Menggunakan SAS. 2011

[23] Y. Hill, L. Lomas, and J. MacGregor, "Students' perceptions of quality in higher education," Qual. Assur. Educ., vol. 11, no. 1, pp. 15-20, 2003.

[24] E. Hazelkorn, "Learning to Live with League Tables and Ranking: The Experience of Institutional Leaders," High. Educ. Policy, vol. 21, no. 2, pp. 193-215, 2008.

[25] K. Struyven, F. Dochy, and S. Janssens, "Students' Perceptions about New Modes of Assessment in Higher Education: a Review," Optimising New Modes Assess. Search Qual. Stand., no. 1, pp. 171-223, 2003.

[26] C. B. Kandiko and M. Mawer, "Student Expectations And Perceptions Of Higher Education A Study Of UK Higher Education," p. 82, 2013.

[27] L. W. Ulmer, L. W. Watson, and D. Derby, "Perceptions of Higher Education Faculty Members on the Value of Distance Education," $Q$. Rev. Distance Educ., vol. 8, no. 1, pp. 59-70, 2007. 